\title{
Overexpression of cyclooxygenase- 2 in noncancerous liver tissue increases the postoperative recurrence of hepatocellular carcinoma in patients with hepatitis B virus-related cirrhosis
}

\author{
${ }^{*} Y i-F u ~ H e ~ M D^{1,2}$, Juan Jin BD1, Wei Wei PhD¹, Yan Chang BD², Bing Hu MD², Chu-Shu Ji MD², \\ Wei-Dong Jia $\mathrm{MD} \mathrm{PhD}^{3}$, Xiao-Qiu Wang $\mathrm{MD}^{4}$, Ke Chen $\mathrm{MD}^{4}$, Jian Chen $\mathrm{MD}^{2}$
}

Y-F He, J Jin,W Wei, et al. Overexpression of cyclooxygenase-2 in noncancerous liver tissue increases the postoperative recurrence of hepatocellular carcinoma in patients with hepatitis $B$ virusrelated cirrhosis. Can J Gastroenterol 2010;24(7):435-440.

BACKGROUND: Many previous studies have evaluated the histopathological features of tumours as risk factors for postoperative recurrence in hepatitis $\mathrm{B}$ virus (HBV)-associated hepatocellular carcinoma (HCC). However, there have been few large studies investigating the relationship between cyclooxygenase-2 (COX-2) expression in noncancerous regions of the liver and postoperative recurrence in the remnant liver, especially in HBV-related HCC.

OBJECTIVE: To evaluate the significance of COX-2 expression levels in noncancerous liver regions as a prognostic indicator of $\mathrm{HCC}$ in patients with HBV-related cirrhosis.

METHODS: A total of 124 patients who underwent curative resection for HCC were reviewed retrospectively. Immunohistochemistry was used to evaluate the expression of COX-2 in noncancerous liver tissue. Clinicopathological variables were compared between patients with high COX-2 expression ( $\mathrm{n}=58$ [COX-2-positive group]) and patients with low COX-2 expression ( $n=66$; [COX-2-negative group]). Univariate and multivariate analyses were performed to identify factors that affected disease recurrence.

RESULTS: There was a significant correlation between COX-2 expression and alanine aminotransferase levels and vascular invasion. The recurrence-free survival rates in the COX-2-positive group were significantly lower than the rates in the COX-2-negative group. On multivariate analysis, the overexpression of COX-2 in noncancerous liver regions was found to be an unfavourable prognostic indicator for the recurrence of HCC.

CONCLUSIONS: The results of the current study suggest that overexpression of COX-2 in noncancerous liver regions is an independent and significant indicator predictive of early recurrence of $\mathrm{HCC}$ in patients with HBV-related cirrhosis.

Key Words: Cyclooxygenase-2; Hepatic resection; Hepatocellular carcinoma; Prognosis; Recurrence

$\mathrm{T}$ he occurence of hepatocellular carcinoma (HCC) after infection with hepatitis $\mathrm{B}$ virus (HBV) and hepatitis $\mathrm{C}$ virus (HCV) is particularly common in Asia and Africa, and its incidence is also increasing in western countries (1). HCC has become the second most common cause of cancer-related death in China, accounting for approximately 137,500 deaths
La surexpression de la COX-2 dans les tissus hépatiques non cancéreux accroît la récurrence postopératoire du cancer hépatocellulaire chez les patients atteints de cirrhose liée au VHB

CONTEXTE : De nombreuses études ont évalué les caractéristiques cytopathologiques des tumeurs comme facteurs de risque de récurrence postopératoire du cancer hépatocellulaire $(\mathrm{CHC})$ associé au virus de l'hépatite B (VHB). Toutefois, peu de grandes études ont porté sur le lien entre l'expression de la cyclooxygénase 2 (COX-2) dans les zones non cancéreuses du foie et la récurrence postopératoire dans les tissus hépatiques résiduels, surtout dans le CHC lié au VHB.

OBJECTIF : Évaluer le rôle des taux d'expression de la COX-2 dans les zones hépatiques non cancéreuses comme indicateurs pronostiques du $\mathrm{CHC}$ chez des patients souffrant d'une cirrhose liée au VHB.

MÉTHODES : En tout, 124 patients ayant subi une résection curative pour $\mathrm{CHC}$ ont été examinés de manière rétrospective. Les auteurs ont utilisé les tests immunohistochimiques pour évaluer l'expression de la COX-2 dans les tissus hépatiques non cancéreux. Ils ont comparé les variables clinicopathologiques des patients présentant une forte expression de la COX-2 ( $\mathrm{n}=58$ [groupe COX-2-positif]) à celles des patients présentant une faible expression de la COX-2 ( $\mathrm{n}=66$ [groupe COX-2-négatif]). Des analyses uni- et multivariées ont permis d'identifier les facteurs ayant influé sur la récurrence de la maladie.

RÉSULTATS : On a noté une corrélation négative entre l'expression de la COX-2 et les taux d'alanine aminotransférase et l'envahissement vasculaire. Les taux de survie sans récurrence dans le groupe COX-2-positif ont été significativement plus bas que dans le groupe COX-2-négatif. À l'analyse multivariée, la surexpression de la COX-2 dans les zones hépatiques non cancéreuses s'est révélée être un indicateur pronostique défavorable à l'égard de la récurrence du $\mathrm{CHC}$.

CONCLUSIONS : Les résultats de la présente étude donnent à penser que la surexpression de la COX-2 dans les zones hépatiques non cancéreuses est un indicateur indépendant et significatif qui permet de prédire la récurrence précoce du $\mathrm{CHC}$ chez des patients souffrant d'une cirrhose liée au VHB.

each year (2). Many investigators have reported a putative link between infection with HBV or HCV, liver cirrhosis and the development of HCC (3).

Cyclooxygenase (COX) is a key enzyme involved in the production of a variety of eicosanoid products. Two COX isoforms have been characterized: COX-1 and COX-2. COX-1 is the

*Co-first authors. ${ }^{1}$ Institute of Clinical Pharmacology, Anhui Medical University; Key Laboratory of Anti-inflammatory and Immune Pharmacology of the Education Ministry of China; ${ }^{2}$ Department of Medical Oncology; ${ }^{3}$ Department of General Surgery; ${ }^{4}$ Department of Pathology, Anhui Provincial Hospital affiliated to Anhui Medical University, Hefei, People's Republic of China

Correspondence: Dr Wei Wei, Institute of Clinical Pharmacology, Anhui Medical University; Key Laboratory of Anti-inflammatory and Immune Pharmacology of the Education Ministry of China, Anhui Medical University, 81 Meishan Road, Hefei 230032, People's Republic of China.

Telephone 086-0551-5161208, fax 086-0551-5161208, e-mail wwei@ahmu.edu.cn

Received for publication May 27, 2008. Accepted January 19, 2010 
housekeeping isoform of COX, while the inducible form, COX-2, responds to many intracellular and extracellular stimuli, and acts in either a proinflammatory or tumorigenic fashion (4).

Recently, a probable association between increased COX-2 expression and the pathophysiology of chronic viral hepatitis and cirrhosis has been documented. The COX-2 gene and protein have been shown to be overexpressed in chronically hepatitic or cirrhotic livers of patients with either HBV or HCV infection (5-9). This overexpression correlated with a greater degree of active inflammation, regenerative activities and progression of fibrosis in the livers of these patients $(5,7,10)$.

Cirrhosis represents the most important predisposing factor because $80 \%$ of HCC cases develop in a cirrhotic background (11). In patients with HBV-related cirrhosis, the five-year cumulative risk of HCC in high endemic areas is $15 \%$, and $10 \%$ in the western hemisphere (12-14). Therefore, effective chemopreventive strategies are needed to benefit individuals at high risk for HCC. HCC in HBV-related cirrhosis could be the result of long-term hepatocellular proliferation associated with active inflammation in the infected livers (15-17). To improve the long-term prognosis after resection of HCC in patients with HBV-related cirrhosis, it is important to prevent postoperative recurrence. To date, many previous studies have evaluated the histopathological features of tumours as risk factors for postoperative recurrence of HCC. However, there have been few large studies investigating the relationship between COX-2 expression in noncancerous regions of the liver and the postoperative recurrence of $\mathrm{HCC}$ in the remnant livers of patients, especially with regard to HBV-related HCC.

The present study evaluated the relationship between the postoperative recurrence of HCC and COX-2 expression in noncancerous regions of remnant livers after resection of HCC in patients with HBV-related cirrhosis.

\section{METHODS}

\section{Patients}

From January 1998 to March 2005, 199 consecutive patients with HBV-related cirrhosis underwent curative hepatic resection for HCC at the Anhui Provincial Hospital (affiliated with the Anhui Medical University), Hefei, People's Republic of China. In the present study, curative hepatic resection was defined as the macroscopic and microscopic removal of all tumours from the liver. Thirty patients were lost to follow-up. Laboratory and clinical data, and noncancerous liver tissue samples were not available for 20 patients; therefore, these patients were excluded from further analysis. Also excluded were three patients who had malignancy other than HCC, 12 patients who died within 30 days after surgery (operative mortality) and 10 patients who underwent transarterial chemoembolization before surgery, which may have affected COX-2 expression levels in noncancerous liver tissues. Therefore, 124 patients with HCC were included in the present retrospective analysis. Follow-up ranged from 41 to 3286 days (median 1432 days). The study was approved by the Ethics Committee of the Anhui Medical University. Informed consent was obtained from each patient. The end of follow-up was defined as either the time of final follow-up or death.

COX-2 immunohistochemistry of noncancerous liver regions Archival formalin-fixed, paraffin-embedded specimens of HCC and surrounding noncancerous liver tissue were obtained. For immunohistochemical COX-2 staining of noncancerous tissue, formalin-fixed, paraffin-embedded $5 \mu \mathrm{m}$ tissue sections were deparaffinized by rinsing with xylene and rehydrated in distilled water through graded alcohol, followed by microwave retrieval of antigen according to standard procedures. Endogenous peroxidase activity was blocked with $0.3 \%$ hydrogen peroxide for $10 \mathrm{~min}$. Nonspecific binding was blocked with $5 \%$ rabbit serum (Dako, Denmark), then incubated with antibody to COX-2 (1:100; Santa Cruz Biotechnology, USA) in tris-buffered saline containing $2 \%$ rabbit serum and $1 \%$ bovine serum albumin for $2 \mathrm{~h}$. Tissues were incubated in the same buffer without the antibody as negative control. This was followed by incubation with biotinylated rabbit antigoat immunoglobulin for 45 min (1:400; Dako, Denmark) and, subsequently, with streptavidin/horseradish peroxidase complex (1:400; Dako, Denmark) for $45 \mathrm{~min}$. The colour reaction was developed in 3,3'-diaminobenzidine substrate solution (Sigma-Aldrich, USA). The sections were then counterstained with Mayer's hematoxylin.

\section{Immunohistochemical evaluation}

The immunohistochemical evaluation was independently performed by two authors (X-QW and $\mathrm{KC}$ ) who were blinded to the clinical data. The COX-2 immunoreactivity levels of each patient were assessed semiquantitatively under light microscope by calculating the average signal intensity (based on a scale from 0 to 3 ) and the proportion of cells showing a positive cytoplasmic stain $(0=$ none; $0.1=$ less than one-tenth; $0.5=$ less than one-half; and $1=$ greater than one-half). The intensity and proportion scores were then multiplied to give an $\mathrm{H}$-score according to the published literature (18-20). The rare cases with discordant scores were re-evaluated and scored on the basis of consensus opinion. A priori, the median value of all cases' H-scores was chosen to be the cut-off for distinguishing COX-2 positive from COX-2 negative in noncancerous tissue samples according to the published literature (20).

\section{Determination of inflammatory activities in noncancerous liver regions}

Modified gradings of inflammatory activity in adjacent liver tissue were measured according to the histological activity index (21-23). The histological activity index consists of four separate scores for different lesion components: periportal necrosis with or without bridging necrosis; intralobular degeneration and focal necrosis; portal inflammation; and fibrosis. The first three categories were measured with a total score range of 0 to 18 ; the first three categories represent grading, whereas the fourth is the method of staging. From this total score, values of 1 to 8 were defined as inactive inflammation, with values of 9 to 18 defining active inflammation.

\section{Parameters}

Recurrence-free survival rates were compared between the two groups using the following clinicopathological variables: host factors were age, sex and liver function tests (such as alanine aminotransferase [ALT, $10 \mathrm{U} / \mathrm{L}$ to $40 \mathrm{U} / \mathrm{L}$ ], albumin [35 g/L to $55 \mathrm{~g} / \mathrm{L}]$ and total bilirubin $[0 \mu \mathrm{mol} / \mathrm{L}$ to $17 \mu \mathrm{mol} / \mathrm{L}])$; tumour factors were alpha-fetoprotein (AFP) level, maximal tumour dimension, number of tumours and histological findings such as capsular formation, vascular invasion (including vascular invasion or tumour thrombi in the portal or hepatic vein) and 
TABLE 1

Relationship between cyclooxygenase-2 (COX-2)

expression in noncancerous liver tissue and clinicopathological parameters in patients with hepatocellular carcinoma

\begin{tabular}{|c|c|c|c|c|}
\hline \multirow[b]{2}{*}{ Parameter } & \multirow[b]{2}{*}{ Patients } & \multicolumn{2}{|c|}{ cOX-2 expression } & \multirow[b]{2}{*}{$\mathbf{P}$} \\
\hline & & Positive & Negative & \\
\hline Age, years & & & & 0.081 \\
\hline$\geq 65$ & 18 & 5 & 13 & \\
\hline$<65$ & 106 & 53 & 53 & \\
\hline Sex & & & & 0.182 \\
\hline Male & 108 & 53 & 55 & \\
\hline Female & 16 & 5 & 11 & \\
\hline \multicolumn{2}{|c|}{ Alanine aminotransferase, $U / L$} & & & $<0.05$ \\
\hline$\geq 80$ & 36 & 30 & 6 & \\
\hline$<80$ & 88 & 28 & 60 & \\
\hline Albumin, g/L & & & & 0.421 \\
\hline$\geq 35$ & 102 & 46 & 56 & \\
\hline$<35$ & 22 & 12 & 10 & \\
\hline \multicolumn{2}{|c|}{ Total bilirubin, $\mu \mathrm{mol} / \mathrm{L}$} & & & 0.296 \\
\hline$\geq 34$ & 21 & 46 & 57 & \\
\hline$<34$ & 103 & 12 & 9 & \\
\hline \multicolumn{2}{|c|}{ Alpha-fetoprotein, $\mu \mathrm{g} / \mathrm{L}$} & & & 0.025 \\
\hline$\geq 400$ & 51 & 30 & 21 & \\
\hline$<400$ & 73 & 28 & 45 & \\
\hline \multicolumn{2}{|c|}{ Tumour size, cm } & & & 0.016 \\
\hline$\geq 5$ & 85 & 46 & 39 & \\
\hline$<5$ & 39 & 12 & 27 & \\
\hline \multicolumn{2}{|l|}{ Tumours } & & & 0.065 \\
\hline Solitary & 81 & 33 & 50 & \\
\hline Multiple & 43 & 25 & 16 & \\
\hline \multicolumn{2}{|c|}{ Capsular formation } & & & 0.995 \\
\hline Present & 77 & 36 & 41 & \\
\hline Absent & 47 & 22 & 25 & \\
\hline \multicolumn{2}{|c|}{ Vascular invasion } & & & $<0.05$ \\
\hline Present & 57 & 40 & 17 & \\
\hline Absent & 67 & 18 & 49 & \\
\hline \multicolumn{2}{|c|}{ Intrahepatic metastases } & & & 0.026 \\
\hline Present & 41 & 25 & 16 & \\
\hline Absent & 83 & 33 & 50 & \\
\hline \multicolumn{2}{|c|}{ Perioperative blood infusion } & & & 0.136 \\
\hline Yes & 66 & 35 & 31 & \\
\hline No & 58 & 23 & 35 & \\
\hline \multicolumn{2}{|c|}{ Type of resection } & & & $<0.05$ \\
\hline Minor & 78 & 29 & 49 & \\
\hline Major & 46 & 29 & 17 & \\
\hline
\end{tabular}

Data presented as $n$ unless indicated otherwise

intrahepatic metastases; multiple tumours were classified as intrahepatic metastases if they were multiple satellite nodules surrounding a main tumour, or a single nodule with a similar or poorer degree of cell differentiation than the main tumour; and operative factors were perioperative blood infusion and type of resection. Transfusions were performed with packed red blood cells or allogeneic blood. Perioperative blood infusion was defined as intraoperative blood infusion and/or postoperative blood infusion within one week after surgery. A resection was considered to be 'major' if three or more liver segments were removed, the remainder were considered to be 'minor' according to the classification proposed by Couinaud (24).

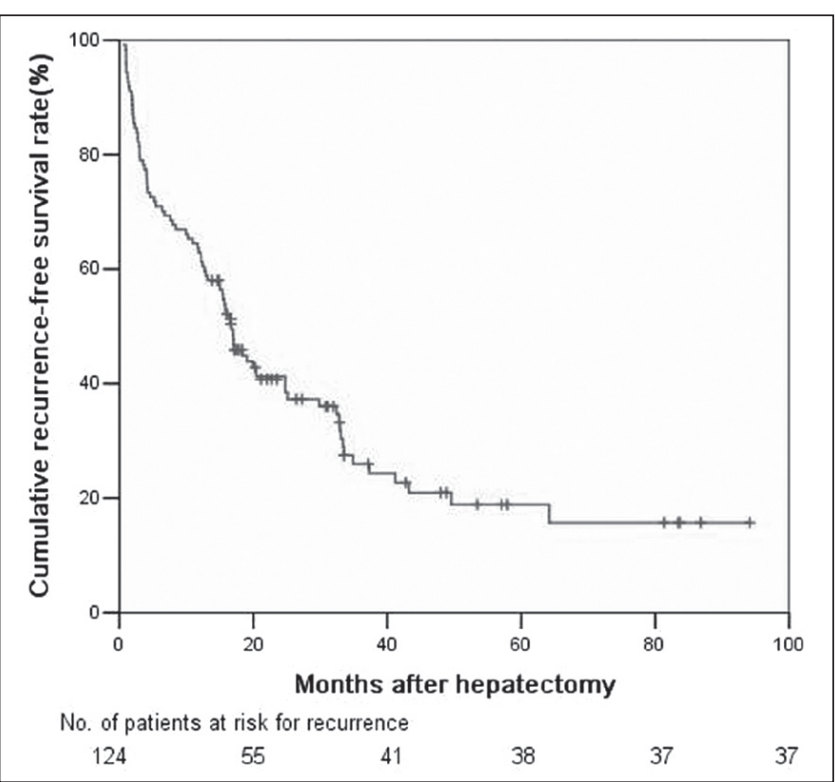

Figure 1) Recurrence-free survival rates of 124 hepatocellular carcinoma patients with hepatitis B virus-related cirrhosis after hepatectomy

Follow-up study

After curative surgery, patients were assessed monthly by physical examination, liver function tests, complete blood cell count and AFP levels. Ultrasonography was performed every three months, and computed tomography $(\mathrm{CT})$ or magnetic resonance imaging was used every six months to detect recurrence. The recurrence of HCC was further diagnosed by additional imaging examinations including helical dynamic CT, lipiodol CT and angiography, together with evaluation of serum AFP levels.

\section{Statistical analysis}

Clinicopathological data according to COX-2 status were compared in univariate analyses with the use of $\chi^{2}$ tests, and in a multivariate logistic model including all variables with $\mathrm{P}<0.05$. The recurrence-free survival rates were estimated using the product-limit method of Kaplan-Meier. Any significant differences in the recurrence-free survival rates were determined using the log-rank test. All variables were entered into a Cox proportional hazard model to identify independent variables that were closely related to the recurrence-free survival rates. All statistical analyses were performed using SPSS version 13.0 (SPSS Inc, USA). A two-sided $\mathrm{P}<0.05$ was considered to be statistically significant.

\section{RESULTS}

Patient characteristics

Clinicopathological characteristics of the study cohort are summarized in Table 1. The patients ranged in age from 19 to 78 years (median age 50 years). Of the 124 patients, 108 were men $(87.1 \%)$ and $16(12.9 \%)$ were women. The one-, threeand five-year recurrence-free survival rates were $62.9 \%, 25.95 \%$ and $18.87 \%$, respectively (Figure 1).

Immunohistochemical assessment of COX-2 expression Figure 2 shows COX-2 expression localized mainly to the cytoplasm in noncancerous hepatocytes. Bile duct epithelium, 


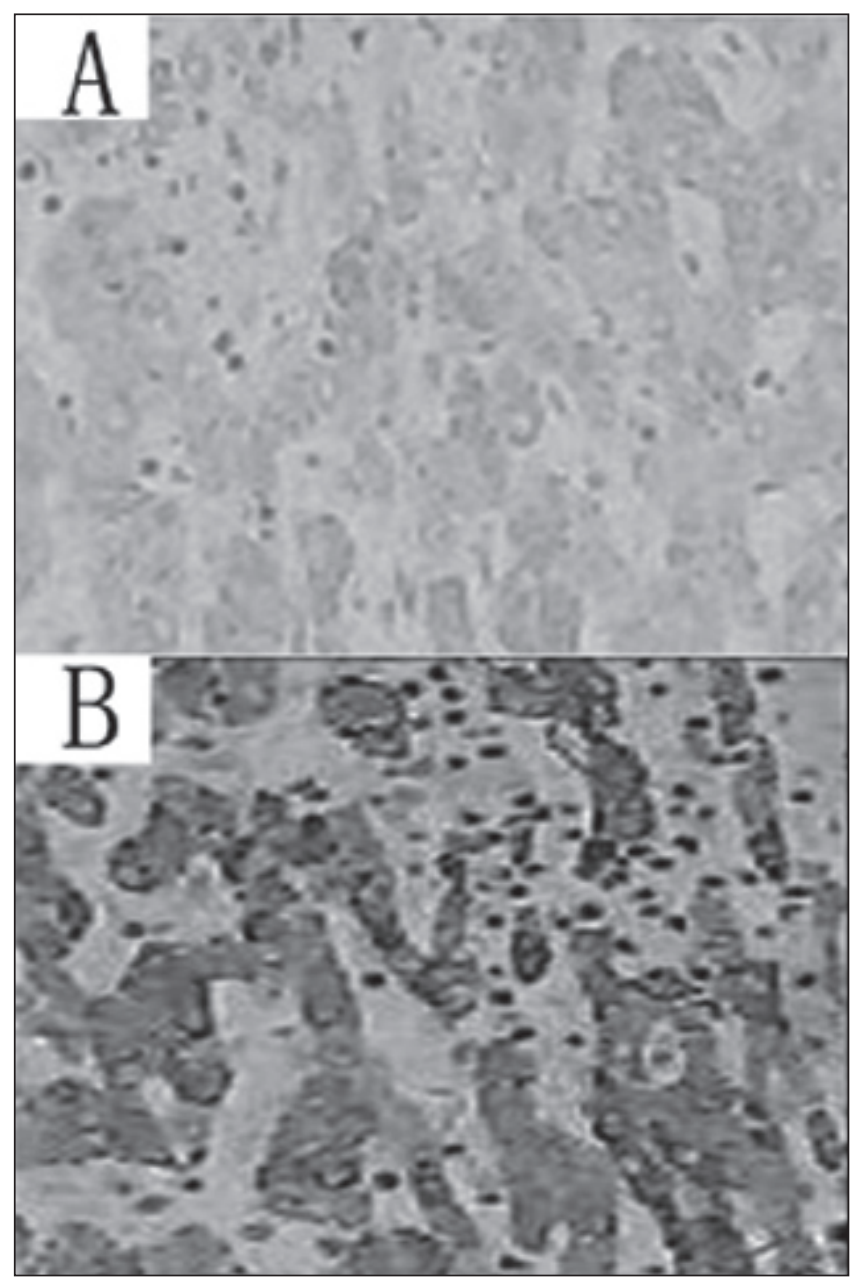

Figure 2) A Cyclooxygenase-2-negative noncancerous tissue (original magnification $\times 200)$. B Cyclooxygenase-2-positive noncancerous tissue (original magnification $\times 200$ )

hepatic artery vascular endothelium, portal vein and sinusoids, Kupffer cells and inflammatory cells did not show significant COX-2 expression. The median percentage of hepatocytes with cytoplasm that stained positive for the monoclonal antibody was $55 \%$ (range $0 \%$ to $100 \%$ ), whereas the median value of the $\mathrm{H}$-scores in the cohort was 1.5. Noncancerous hepatocytes with an $\mathrm{H}$-score exceeding 1.5 (ie, noncancerous tissues with a staining intensity score of 2 and with $50 \%$ or more positive cytoplasm, or with a staining intensity score of 3 and $50 \%$ or more positive cytoplasm) were considered to be COX-2 positive. Of the 124 noncancerous tissue samples, 58 (46.8\%) were COX-2 positive. Table 1 compares the host, tumour and operative factors according to COX-2 expression in a univariate analysis. A multivariate stepwise logistic model based on a backward elimination procedure for model selection showed that the expression of COX-2 was significantly associated with ALT level $(\mathrm{P}<0.05)$ and vascular invasion $(\mathrm{P}<0.05)$.

To examine the possible involvement of inflammation in COX-2 induction, the 124 noncancerous tissue samples were divided into two groups (by $\mathrm{X}-\mathrm{QW}$ and $\mathrm{KC}$ ) by pathological survey according to their extent of inflammation. Active inflammation was noted in 48 of $58 \mathrm{COX}$-2-positive livers and in eight of 66 COX-2-negative livers. A significant correlation
TABLE 2

Relationship between cyclooxygenase-2 expression and inflammation status in noncancerous liver tissue

\begin{tabular}{lccc}
\hline & \multicolumn{2}{c}{ Cyclooxygenase-2 expression } & \multirow{2}{*}{ Inflammation status } \\
\cline { 2 - 3 } & Positive & Negative & $\mathbf{P}$ \\
\hline Active & 48 & 8 & $<0.05$ \\
Inactive & 10 & 58 & \\
\hline
\end{tabular}

Data presented as $n$ unless indicated otherwise

was found between high COX-2 expression in noncancerous tissue and inflammation $(\mathrm{r}=0.708 ; \mathrm{P}<0.05)$ (Table 2).

Significant factors regarding recurrence-free survival

The recurrence-free survival rate in the COX-2-positive group was significantly lower compared with the rate in the COX-2negative group (Figure 3$)(\mathrm{P}<0.05)$. The one-, three- and fiveyear recurrence-free survival rates were $46.6 \%, 13.4 \%$ and $4.5 \%$, respectively, in the COX-2-positive group and $77.3 \%$, 35.5\% and $29.8 \%$, respectively, in the COX-2 negative group.

In the univariate analysis of recurrence-free survival, significant differences were observed in the following 11 variables: COX-2 expression level $(\mathrm{P}<0.05)$, intrahepatic metastasis $(\mathrm{P}<0.05)$, ALT level $(\mathrm{P}<0.05)$, total bilirubin level $(\mathrm{P}=0.037)$, albumin level $(\mathrm{P}=0.016)$, capsular formation $(\mathrm{P}=0.032)$, vascular invasion $(\mathrm{P}<0.05)$, AFP level $(\mathrm{P}<0.05)$, number of nodules $(\mathrm{P}<0.05)$, maximal tumour dimension $(\mathrm{P}=0.020)$ and blood infusion $(\mathrm{P}=0.012)$. The results of the multivariate analysis are shown in Table 3. COX-2 expression level $(\mathrm{P}<0.05)$, vascular invasion $(\mathrm{P}<0.05)$ and intrahepatic metastasis $(\mathrm{P}<0.05)$ were shown to be independent and significant predictors of recurrence-free survival.

\section{DISCUSSION}

The prognosis of HCC is generally unfavourable. Although primary tumours are curatively resected, $50 \%$ to $60 \%$ of patients experience recurrence within five years $(25,26)$. All patients in the present study had HBV-induced chronic liver cirrhosis, and it is important to note this background prevalence when considering the $81 \%$ recurrence rate of HCC observed. This caused loss of hepatic reserve and subsequently limited the extent of resection for HCC patients in whom there was frequent microscopic intrahepatic metastasis, even at an early tumour stage. This also increased the risk of missing undetected minute lesions - even after an apparently complete resection. Cirrhosis may represent a field of cancerization associated with the development of a new metachronous HCC after resection (27).

It is believed that the main cause of disease recurrence is intrahepatic metastasis (28) or metachronous, multicentric carcinogenesis $(29,30)$. However, adequate techniques to clarify the clonality between multicentric occurrence and intrahepatic metastasis have yet to be established. Therefore, an investigation of both noncancerous and cancerous regions is required to evaluate postoperative recurrence including multicentric occurrence.

In the present study, we demonstrated that COX-2 overexpression in the presence of background liver cirrhosis was significantly associated with the recurrence or new development of HCC, which may be an independent and significant prognostic indicator in patients with HBV-related HCC after curative hepatic resection. The recurrence-free survival rate 


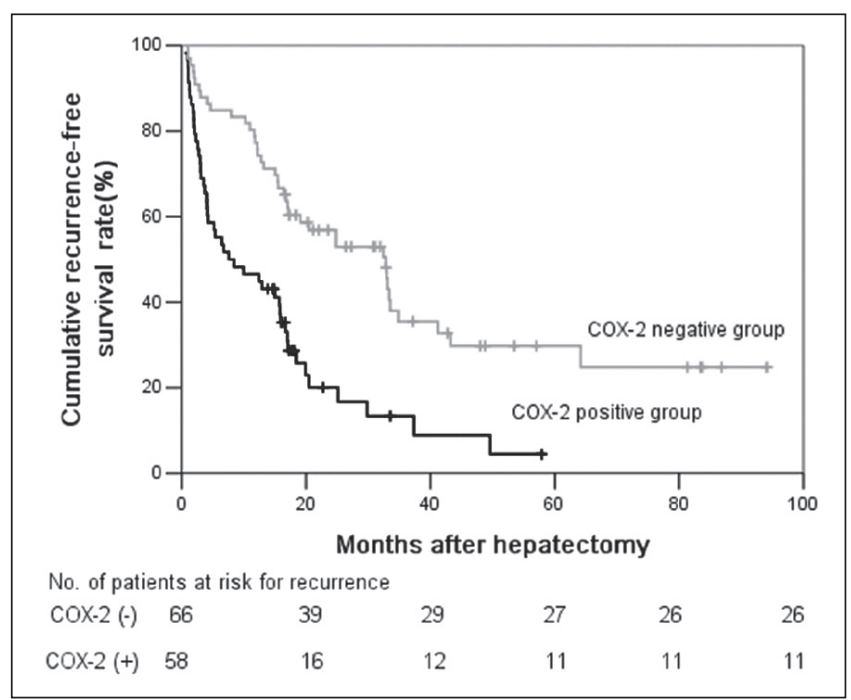

Figure 3) Recurrence-free survival rates after curative hepatic resection. The recurrence-free survival rate in the cyclooxygenase2-positive group (COX-2) ( $n=58)$ was significantly lower compared with the rate in the COX-2-negative group $(n=66 ; P<0.05)$. No Number

in the COX-2-positive group was significantly lower than the rates in the COX-2-negative group. Among the factors investigated in the current study, COX-2 expression level proved to be one of the most powerful indicators. To the best of our knowledge, the present study is the first large report from the Chinese mainland to reveal the prognostic significance of COX-2 overexpression in the livers of HCC patients with HBV-related cirrhosis.

Data from the current study partly confirm the observation by Kondo et al (5), who reported a significant association between COX-2 expression and remnant liver recurrence in patients with HCV infection. However, their study was performed on patients with either chronic hepatitis or cirrhosis, and the cirrhotic patients had a higher expression of COX-2 in the liver. Therefore, Kondo et al could not rule out the possibility that the difference found in the disease-free survival rate might be due to the development of cirrhosis. In contrast, all of the patients in the present study were diagnosed with cirrhosis by pathological examination. Thus, it could be said that the overexpression of COX-2 in diseased liver is associated with recurrence of $\mathrm{HCC}$ in patients with $\mathrm{HBV}$-related cirrhosis.

Previous studies of HBV-infected patients did not reveal a significant relationship between COX-2 expression level and inflammatory activity in noncancerous liver regions $(31,32)$. However, two studies $(5,7)$ in patients with $\mathrm{HCV}$ infection showed a significant relationship between COX-2 expression and inflammatory activity in noncancerous liver regions. Our data also revealed a significant association between COX-2 expression and inflammatory activity in the noncancerous regions of cirrhotic livers of patients with HBV-related HCC. The results of the present analysis suggest that induction of COX-2 may be attributable to active inflammation in cirrhotic livers (Table 3). This is reasonable, given the fundamental action of COX-2 as a mediator of inflammation. COX-2 is a rate-limiting enzyme in the conversion of arachidonic acid to bioactive prostaglandins, such as prostaglandin E2, which
TABLE 3

Multivariate analyses of recurrence-free survival in patients with hepatocellular carcinoma who underwent hepatic resection

\begin{tabular}{lcccc}
\hline Variable & Coefficient & HR & 95\% Cl & P \\
\hline $\begin{array}{c}\text { COX-2 (positive versus } \\
\text { negative) }\end{array}$ & 0.845 & 2.327 & $1.465-3.697$ & $<0.05$ \\
$\begin{array}{c}\text { Vascular invasion (present } \\
\text { versus absence) }\end{array}$ & 0.657 & 1.931 & $1.224-3.040$ & $<0.05$ \\
$\begin{array}{c}\text { Intrahepatic metastases } \\
\text { (present versus absent) }\end{array}$ & 0.636 & 1.890 & $1.195-2.985$ & $<0.05$ \\
\hline
\end{tabular}

coX-2 Cyclooxygenase-2

are able to efficiently suppress $\mathrm{T}$ cell immune responses in a regulatory manner and elicit an inhibitory immune profile (33). However, T cell failure was significantly associated with HBV viral replication level (34). Persistent HBV replication may increase the incidence of recurrence after surgery. There was also significant correlation between COX-2 expression in noncancerous liver tissues and serum ALT levels, which has been recognized as a serological marker reflecting necroinflammatory processes in chronic liver diseases (21). These results suggest that COX-2 is related to background necroinflammatory and regenerative activity, and these pathological changes may result in the recurrence of HCC.

The other explanation for $\mathrm{COX}-2$ contribution to recurrence or new development of $\mathrm{HCC}$ is that COX-2 in cirrhotic livers acts as a 'landscaping' tumour promoter $(4,35)$. Recent experimental data $(4,36)$ have shown that COX-2 derived from the stromal component may promote tumour growth by producing bioactive prostaglandins, which act angiogenetically or immunosuppressively, and affect carcinoma cells in a paracrine fashion. Therefore, according to the landscaper hypothesis (35), COX-2 derived from cirrhotic liver may promote the growth of newly developed or metastatic malignant cells. The present study demonstrated a significant correlation between tumour vascular invasion and COX-2 in noncancerous liver tissues, suggesting that COX-2 may also be involved in angiogenesis, and portal and hepatic vein invasion in $\mathrm{HCC}$ in a paracrine pattern. COX-2 may play a specific role in HBVinduced chronic liver disease. HBV X protein has recently been found to induce vascular endothelial growth factor expression and angiogenesis in $\mathrm{HBV}$-infected noncancerous liver tissue, which may contribute to hepatocarcinogenesis (37). HBV X protein has also been shown to induce COX-2 expression $(38,39)$. Together with our finding of a positive correlation between vascular invasion and COX-2 levels in noncancerous liver tissue, it is reasonable to suggest a role for COX-2 in angiogenesis, portal and hepatic vein invasion and hepatocarcinogenesis. However, the exact role of COX-2 in $\mathrm{HCC}$ is less clear. Further investigation to more clearly delineate the role of COX-2 in chronic liver disease and HCC recurrence and/or development is needed.

A noteworthy limitation of the present study was that we could not evaluate the significance of baseline HBV DNA levels as a prognostic indicator in HCC patients with HBV-related cirrhosis because HBV DNA was not detected in some of the patients. It is now recognized that the baseline HBV DNA level before hepatic resection is a predictive factor for HCC recurrence and/or development (40-43). 


\section{SUMMARY}

The results of the present study showed that the overexpression of COX-2 in the presence of background liver cirrhosis is associated with early recurrence and/or new development of HCC after curative surgery in HBV-related cirrhotic patients. This is of clinical importance because pharmacological inhibition of COX-2 activity may improve patient prognosis, although further analysis of the functional significance of COX-2 is required.

ACKNOWLEDGEMENTS: The authors thank the staff members in the Department of Medical Oncology at the Anhui Provincial Hospital Affiliated with Anhui Medical University for their helpful suggestions and assistance.

FUNDING: This work was supported by the National Natural Science Fund of China (NO: 30572356), Natural Science Fund of Anhui Province (NO: 050430903) and the Science and Technology Planning of Anhui Province (NO: 06013133B).

\section{REFERENCES}

1. El-Serag HB, Mason AC. Rising incidence of hepatocellular carcinoma in the United States. N Engl J Med 1999;340:745-50.

2. Lau WY, Ho S, Leung TW, et al. Selective internal radiation therapy for nonresectable hepatocellular carcinoma with intraarterial infusion of ${ }^{90}$ Yttrium microspheres. Int J Radiat Oncol Biol Phys 1998;40:583-92.

3. Akriviadis EA, Llovet JM, Efremidis SC, et al. Hepatocellular carcinoma. Br J Surg 1998;85:1319-31.

4. Williams CS, Mann M, DuBois RN. The role of cyclooxygenases in inflammation, cancer, and development. Oncogene 1999;18:7908-16.

5. Kondo M, Yamamoto H, Nagano $\mathrm{H}$, et al. Increased expression of COX-2 in noncancerous liver tissue is associated with shorter disease-free survival in patients with hepatocellular carcinoma. Clin Cancer Res 1999;5:4005-12.

6. Koga H, Sakisaka S, Ohishi M, et al. Expression of cyclooxygenase-2 in human hepatocellular carcinoma: Relevance to tumor dedifferentiation. Hepatology 1999;29:688-96.

7. Morinaga S, Yamamoto Y, Noguchi Y, et al. Cyclooxygenase-2 mRNA is up-regulated in cirrhotic or chronic hepatitis liver adjacent to hepatocellular carcinoma. J Gastroenterol Hepatol 2002;17:1110-6.

8. Mohammed NA, Abd El-Aleem SA, El-Hafiz HA, McMahon RF. Distribution of constitutive (COX-1) and inducible (COX-2) cyclooxygenase in postviral human liver cirrhosis: A possible role for COX-2 in the pathogenesis of liver cirrhosis. J Clin Pathol 2004;57:350-4.

9. Sung YK, Hwang SY, Kim JO, Bae HI, Kim JC, Kim MK. The correlation between cyclooxygenase-2 expression and hepatocellular carcinogenesis. Mol Cells 2004;17:35-8.

10. Cheng J, Imanishi H, Iijima H, et al. Expression of cyclooxygenase-2 and cytosolic phospholipase A2 in the liver tissue of patients with chronic hepatitis and liver cirrhosis. Hepatol Res 2002;23:185-95.

11. Llovet JM, Burroughs A, Bruix J. Hepatocellular carcinoma. Lancet 2003;362:1907-17.

12. Fattovich G, Stroffolini T, Zagni I, Donato F. Hepatocellular carcinoma in cirrhosis: Incidence and risk factors. Gastroenterology 2004;127(5 Suppl 1):S35-50.

13. Ikeda K, Saitoh S, Koida I, et al. A multivariate analysis of risk factors for hepatocellular carcinogenesis: A prospective observation of 795 patients with viral and alcoholic cirrhosis. Hepatology 1993;18:47-53.

14. Gentilini P, Melani L, Riccardi D, Casini Raggi V, Romanelli RG. Hepatocellular carcinoma and viral cirrhosis. Hepatology 1994;20:764-5.

15. Cougot D, Neuveut C, Buendia MA. HBV induced carcinogenesis. Clin Virol 2005;34(Suppl 1):S75-78.

16. Marotta F, Vangieri B, Cecere A, Gattoni A. The pathogenesis of hepatocellular carcinoma is multifactorial event. Novel immunological treatment in prospect. Clin Ter 2004;155:187-99.

17. Oliveri F, Brunetto MR, Actis GC, Bonino F. Pathobiology of chronic hepatitis virus infection and hepatocellular carcinoma (HCC). Ital J Gastroenterol 1991;23:498-502.

18. Al-Haddad S, Zhang Z, Leygue E, et al. Psoriasin (S100A7) expression and invasive breast cancer. Am J Pathol 1999;155:2057-66
19. Handra-Luca A, Bilal H, Bertrand JC, et al. Extra-cellular signal-regulated ERK-1/ERK-2 pathway activation in human salivary gland mucoepidermoid carcinoma: Association to aggressive tumor behavior and tumor cell proliferation. Am J Pathol 2003; 163:957-67

20. Olaussen KA, Dunant A, Fouret P, et al. DNA repair by ERCC1 in non-small-cell lung cancer and cisplatin-based adjuvant chemotherapy. N Engl J Med. 2006;355:983-91.

21. Desmet VJ, Gerber M, Hoofnagle JH, Manns M, Scheuer PJ. Classification of chronic hepatitis: Diagnosis, grading and staging. Hepatology 1994;19:1513-20.

22. Ishak K, Baptista A, Bianchi L, et al. Histological grading and staging of chronic hepatitis. J Hepatol 1995;22:696-9.

23. Assy N, Minuk GY. Serum aspartate but not alanine aminotransferase levels help to predict the histological features of chronic hepatitis $\mathrm{C}$ viral infections in adults. Am J Gastroenterol 2000;95:1545-50.

24. Couinaud C. Anatomic principles of left and right regulated hepatectomy. Technics J Chir 1954;70:933-66.

25. Wu CC, Chen JT, Ho WL, et al. Liver resection for hepatocellular carcinoma in octogenarians. Surgery 1999;125:332-8.

26. Qiang L, Huikai L, Butt K, Wang PP, Hao X. Factors associated with disease survival after surgical resection in Chinese patients with hepatocellular carcinoma. World J Surg 2006;30:439-45.

27. Bilimoria MM, Lauwers GY, Doherty DA, et al. Underlying liver disease, not tumor factors, predicts long-term survival after resection of hepatocellular carcinoma. Arch Surg 2001;136:528-35.

28. Poon RT, Fan ST, Lo CM, Liu CL, Wong J. Intrahepatic recurrence after curative resection of hepatocellular carcinoma: Long-term results of treatment and prognostic factors. Ann Surg 1999;229:216-22.

29. Takenaka K, Adachi E, Nishizaki T, et al. Possible multicentric occurrence of hepatocellular carcinoma: A clinicopathological study. Hepatology 1994;19:889-94.

30. Kumada T, Nakano S, Takeda I, et al. Patterns of recurrence after initial treatment in patients with small hepatocellular carcinoma. Hepatology 1997;25:87-92.

31. Tang TC, Poon RT, Lau CP, Xie D, Fan ST. Tumor cyclooxygenase-2 levels correlate with tumor invasiveness in human hepatocellular carcinoma. World J Gastroenterol 2005;11:1896-902.

32. Cheng AS, Chan HL, Leung NW, et al. Expression of cyclooxygenase-2 in chronic hepatitis B and the effects of anti-viral therapy. Aliment Pharmacol Ther 2002;16:251-60.

33. Bryn T, Yaqub S, Mahic M, et al. LPS-activated monocytes suppress T-cell immune responses and induce FOXP3 + T cells through a COX-2-PGE2-dependent mechanism. Int Immunol 2008;20:235-45.

34. You J, Sriplung H, Geater A, et al. Effect of viral load on T-lymphocyte failure in patients with chronic hepatitis B. World J Gastroenterol 2008;14:1112-9.

35. Kinzler KW, Vogelstein B. Landscaping the cancer terrain. Science 998;280:1036-7.

36. Gasparini G, Longo R, Sarmiento R, Morabito A. Inhibitors of cyclooxygenase 2: A new class of anticancer agents? Lancet Oncol 2003;4:605-15.

37. Moon EJ, Jeong CH, Jeong JW, et al. Hepatitis B virus X protein induces angiogenesis by stabilizing hypoxia-inducible factor-1 alpha. FASEB J 2004;18:382-4.

38. Lara-Pezzi E, Gomez-Gaviro MV, Galvez BG, et al. The hepatitis B virus $\mathrm{X}$ protein promotes tumor cell invasion by inducing membrane-type matrix metalloproteinase- 1 and cyclooxygenase- 2 expression. J Clin Invest 2002;110:1831-8.

39. Cheng AS, Chan HL, Leung WK, et al. Expression of HBx and COX-2 in chronic hepatitis B, cirrhosis and hepatocellular carcinoma: Implication of HBx in upregulation of COX-2. Mod Pathol 2004;17:1169-79.

40. Kim BK, Park JY, Kim do Y, et al. Persistent hepatitis B viral replication affects recurrence of hepatocellular carcinoma after curative resection. Liver Int 2008;28:393-401.

41. Hung IF, Poon RT, Lai CL, et al. Recurrence of hepatitis B-related hepatocellular carcinoma is associated with high viral load at the time of resection. Am J Gastroenterol 2008;103:1663-73.

42. Huang Y, Wang Z, An S, et al. Role of hepatitis B virus genotypes and quantitative HBV DNA in metastasis and recurrence of hepatocellular carcinoma. J Med Virol 2008;80:591-7.

43. Kubo S, Tanaka H, Takemura S, et al. Effects of lamivudine on outcome after liver resection for hepatocellular carcinoma in patients with active replication of hepatitis B virus. Hepatol Res 2007;37:94-100. 


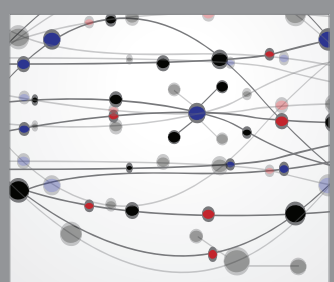

The Scientific World Journal
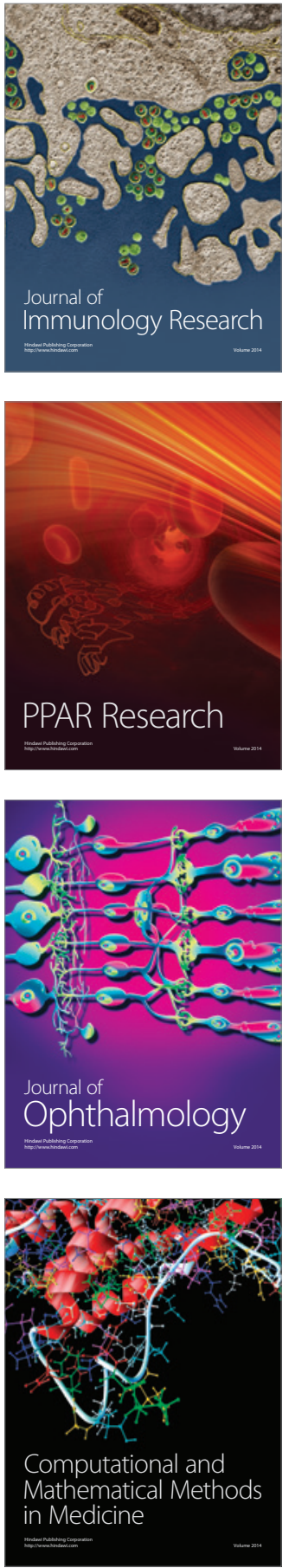

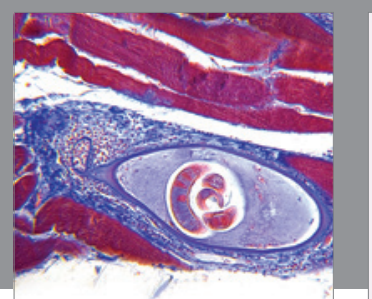

Gastroenterology Research and Practice

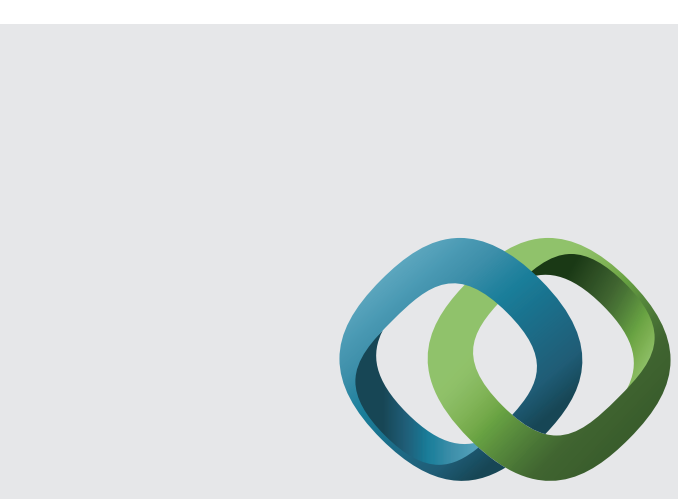

\section{Hindawi}

Submit your manuscripts at

http://www.hindawi.com
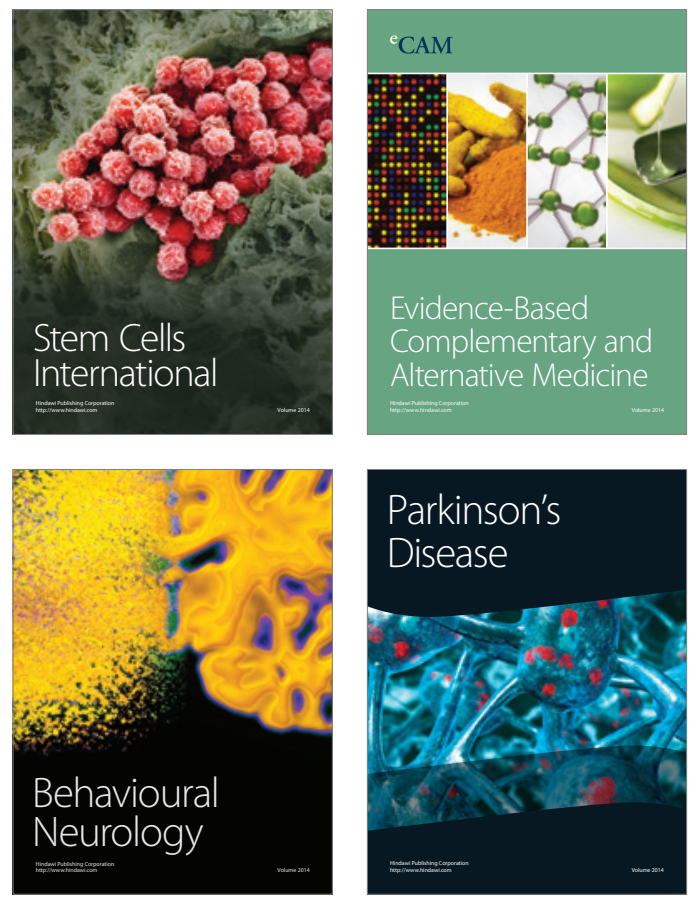
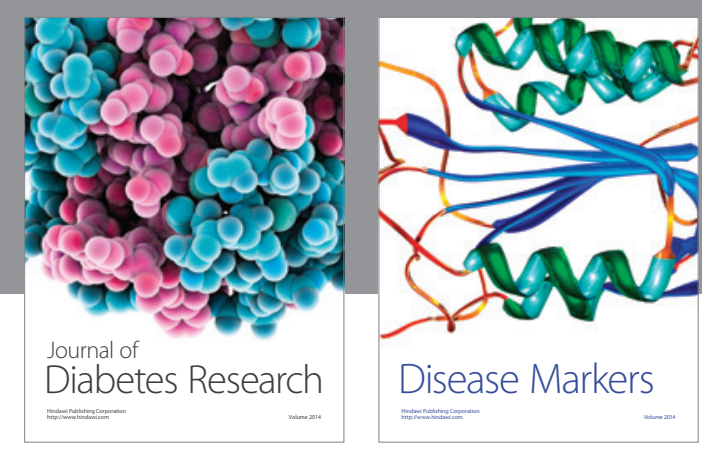

Disease Markers
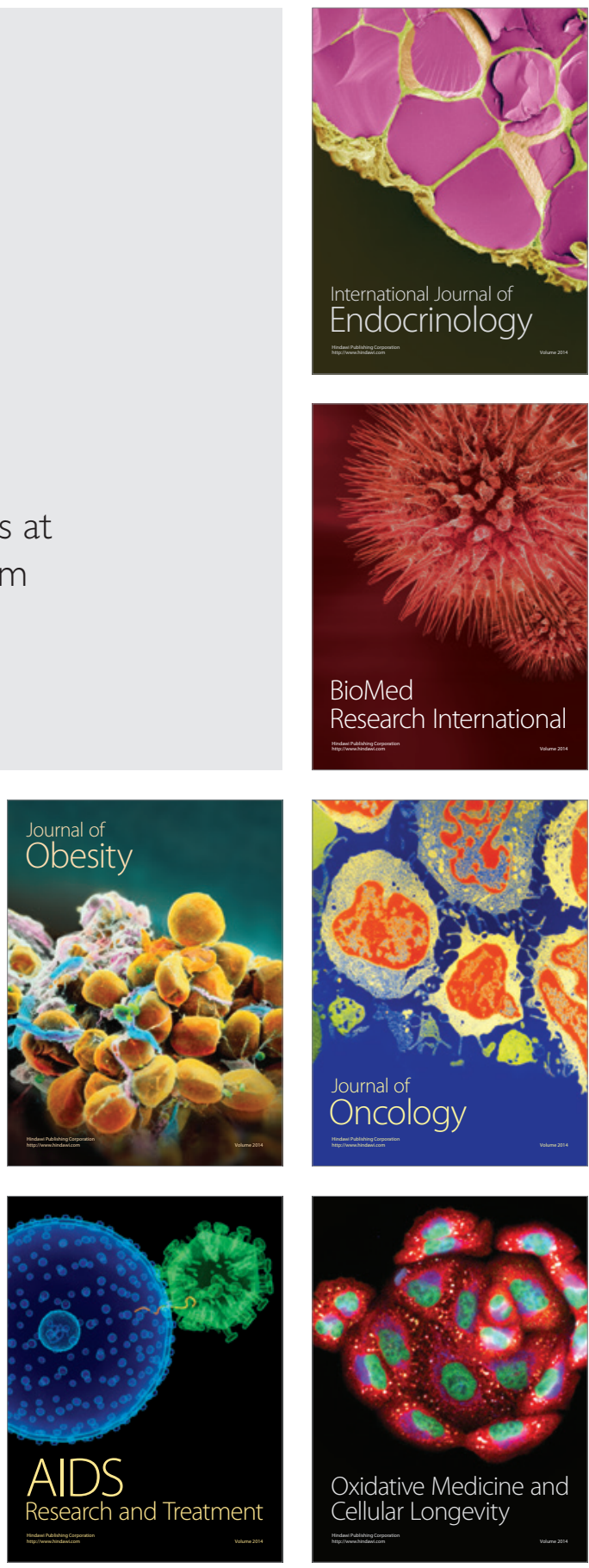